\title{
Youth, Dirt, and the Spatialization of SUBJECTIVITY: An InTERSECTIONAL Approach to White RuRAl IMAginaries
}

\author{
Kate CAIRns
}

\begin{abstract}
Canada's rural idyll is embedded within the colonial legacy of a white settler society; however, little research has examined how class and gender uphold this articulation of rurality and whiteness. This article draws on ethnographic research with white, working-class rural youth to develop an intersectional analysis of rural imaginaries. The analysis shows how youth construct their own rural identities through racialized representations of urban and global "others." I argue that these racist place-narratives must be understood in the context of competing discourses of rurality in Canada: the romanticized pure white rural of colonial history, and the pathologized poor white rural of a cosmopolitan future. Even as youth locate their gendered performances within the rural idyll, they are marked as "dirts" by their classed, rural status. By inscribing racist discourses onto others, youth resist the classist imagery projected onto their community and thereby reclaim a pure white rural idyll.
\end{abstract}

Keywords: rural, whiteness, intersectionality, youth, space, subjectivity

Résumé. L'idylle de la ruralité du Canada est intégrée dans l'héritage colonial d'une société de colon blanc; néanmoins, peu de recherches examinent toutefois comment les classes sociales et le genre soutiennent cette articulation de la ruralité et de la blancheur. Cet article s'appuie sur une recherche ethnographique auprès de jeunes ruraux blancs de classe moyenne afin de développer une analyse intersectionelle des imaginaires ruraux. L'analyse démontre comment les jeunes construisent leurs propres identités rurales à travers des représentations racialisées des « autres » à la fois urbains et globaux. Je soutiens que ces lieux-narratifs racistes doivent être appréhendés dans un contexte de discours concurrentiels de la ruralité au Canada: nommément, la ruralité pure, blanche et romancée de l'histoire coloniale, et la ruralité pathologisé pauvre et blanche du futur cosmopolite du Canada. En inscrivant des discours racistes sur les autres, les jeunes résistent à l'imagerie classiste projeté sur leurs communautés, et réclament ainsi une idylle rurale, blanche et pure.

Mots clés: rurale, blancheur, intersectionelle, les jeunes, espace, subjectivité 
Narratives of rurality perform a critical role within Canadian mytholoI1 gies (Shields 1991). Despite the fact that less than one-fifth of the country resides in rural municipalities (Mitchell 2005:468), Canadians are consistently reminded that they remain a citizenry in close contact with nature (Baldwin et al. 2011). From Group of Seven paintings to Mountain Equipment Co-op advertisements (Van der Kloet 2009), a range of cultural texts locate the nation within a vast Canadian wilderness (Grace 2002). This imagined geography erases violent histories of colonization through spatial stories of empty land peacefully settled by rugged European settlers (Furniss 1999; Lawrence 2002) and sustains the racial coding of rurality as a space of whiteness (Razack 2002).

Contrasting the idealized rural of Canada's colonial history, much current media and policy discourse represents rural communities as "backward," targeting these seemingly anachronistic spaces as barriers to Canada's progressive future (Corbett 2006). Government-commissioned reports warn that rural communities are "increasingly disconnected from the creative economy" (Martin and Florida 2009:27), while news media highlight the growing "divide between rural Canada and its metropolitan centres" (Globe and Mail 2009:A4). This spatial story constructs the rural as a national problem, imagined as a stagnant space of intolerance within a vibrant, multicultural Canada (O'Connell 2010). Whether celebrating Canada's rural history or lamenting its rural future, both of these spatial discourses associate rurality with whiteness. How do these contradictory discourses of rurality operate within contemporary Canadian imaginaries? What kinds of subjects are constituted through their intersection?

This article brings an intersectional analysis to processes of racialization in rural youths' place-narratives, analyzing the class and gender dynamics at play in the construction of a white rural imaginary. Drawing on ethnographic research with students in a predominantly white, working-class school in rural Ontario, I examine how young people construct their own rural and Canadian identities through racialized representations of urban and global "others." Locating themselves within a quiet and open countryside, students define their own rural location in opposition to a dirty and dangerous city. These spatial identifications extend to the international sphere, as students claim their place within a peaceful and picturesque Canada and regard global others with a mixture of wonder and fear.

Drawing on literature that examines racialization within the mutual constitution of subjectivity and space (Razack 2002), I show how students mobilize racial spatial imaginaries to locate themselves within a pure, white rural. Beyond individual racist attitudes, I argue that these 
place-narratives must be understood in the context of contradictory discourses of whiteness and rurality in Canada: the romanticized pure white rural of Canada's colonial history, and the pathologized poor white rural of Canada's cosmopolitan future. The young people in this study invest heavily in the discourse of the rural idyll, enacting masculinities characterized by dominance over the rural landscape, and femininities centring on notions of a safe rural community. At the same time, they struggle to disidentify with the label of "dirt," a category assigned to poor, rural youth. By analyzing the significance of dirt in students' place-narratives, I show how spatial dynamics of racialization intersect with class distinction, as students navigate their positioning within landscapes of purity and pollution. By inscribing polluting discourses onto racial and urban "others," these young people resist the classist imagery that is projected onto their community and thereby reclaim a pure, white, rural idyll.

The article generates new insights into the spatial organization of racism by revealing the classed and gendered interplay of rurality and whiteness in Canada. Building on recent scholarship advocating for intersectional approaches to whiteness (Steyn and Conway 2010), the analysis demonstrates how contemporary discourses of rurality pathologize working-class, rural whites in ways that sustain broader structures of white supremacy (Shirley 2010).

\section{Race, Space, and Subjectivity}

This article builds on the work of critical race and spatial theorists who explore processes of racialization within the production of subjectivity and space (Razack 2002:8). My analysis is informed by Massey's relational notion of place as a "lived world of a simultaneous multiplicity of spaces" (1994:3). Approaching rurality as both a socio-spatial construct and lived geography (Little 2002), I explore how young people produce their own identities in opposition to "others" located "elsewhere" (Massey 1995).

Sociology of youth scholarship shows how young people construct spatial boundaries to demarcate social groupings (Dillabough and Kennelly 2010; Pomerantz 2008). These boundaries often align with structural differences, for "topographies of the public and the private, the foreign and the familiar are powerfully classed, gendered, and racialized" (Reay and Lucey 2000:412). However, with few notable exceptions (Hayes 2004; Kenway et al. 2006), research with rural youth has tended to emphasize issues of gender, class, and locality, with significantly less attention to race. By failing to explore dynamics of racialization, rural youth scholarship reproduces a rural imaginary where "whiteness 
is normative and ubiquitous" (Mackey 1999:94). In this way, studies of rural youth may work to sustain racialized binaries, whereby the rural's apparent racelessness (or normative whiteness) confirms the coding of "urban" as "black" (Goldberg 1993).

Sociological investigations of rural youth can gain insight from scholarship "confronting the spatial logic of race" (Baldwin et al. 2011:11). This literature demonstrates that rurality is often perceived as a space of whiteness, rooted in legacies of the British countryside that conjure images of blond-haired children playing innocently in open fields (Jones 1999; Panelli et al. 2009). This association takes on particular significance in the Canadian context, where it is bolstered by "frontier narratives" of rugged male settlers traversing Canada's harsh landscape (Furniss 1999). The rural/urban binary emerges out of colonialism as a spatialization of race, as "nature was troped as a site of moral and racial purity: the true foundation of the nation, and the true home of its original settlers" (Braun 2003:197). Such familiar tales reproduce a spatially articulated Canadian "essence" echoing the colonial ideal that, as a northern nation, Canada's citizens possess a distinct "racial character" (Berger 1966:3). As Bonita Lawrence asserts "Canadian national identity is deeply rooted in the notion of Canada as a vast northern wilderness, the possession of which makes Canadians unique and 'pure' of character" (2002:23). Thus, the idealized inhabitant of Canada's rural imaginary is produced as a masculine white subject that simultaneously requires and denies both the Aboriginal subject, who secures a settler identity, and the racialized urban other, who confirms the whitened space of Canadian wilderness (Razack 2002).

While Canada's rural spaces continue to be associated with whiteness, contemporary rural imaginaries are also deeply classed. Amid discourses of multiculturalism and global economic competitiveness, rural spaces are commonly represented as stagnant and old-fashioned, positioned as a threat to Canada's progressive reputation (Corbett 2006; O'Connell 2010). Class operates in and through racialization to produce contemporary rural imaginaries, yet as Jarocz and Lawson note, there is little rural research that "analyzes the geographic dimensions of whiteness and place-specific constructions of class-based subjectivities" (2002:10). This gap in the literature reflects the need for modes of theorizing that move beyond monolithic constructions of whiteness, to attend to its intersection with gender, class, and geography (Steyn and Conway 2010). Recent scholarship on the category of "white trash" has drawn attention to the "diacriticals of class and regional difference that importantly score the social landscape of white identity" (Hartigan 2003:101; Wray 2006). This research reveals a paradoxical process whereby class 
distinctions among whites may work to uphold structures of white supremacy. Boundary terms like "white trash" and "redneck" mark distance from an undesirable white other, and thus operate in the service of "keeping whiteness 'pure' - an untainted and superior standard and status" (Shirley 2010:35). Thus, an intersectional analysis is crucial to understanding "the material and symbolic power of whiteness, while identifying its relationality and contextuality" (Levine-Rasky 2002:3).

Spatial imaginaries offer a rich analytic site in which to deepen intersectional understandings of whiteness. In the sections that follow, I explore how white, working-class rural youth locate themselves through relational constructions of place. While previous research has traced the ways in which "human bodies and social collectives are united and divided on landscapes of purity and pollution" (Moore et al. 2003:29), my analysis reveals how such landscapes may be multiple and overlapping, positioning rural youth within the contradictory space of both the pure and the profane. Even as these young people locate their gendered performances of rurality within a pure white rural idyll, they are simultaneously marked as "dirts" by their marginalized class and spatial status. Thus, I argue that an intersectional analysis is crucial to understanding how students construct their own spatial purification through contaminating discourses of the urban and racial other.

\section{Study Background}

This article emerges from a larger study exploring how rural youth envision their futures in neoliberal times. Located in "Fieldsville," a small, predominantly white and working-class rural community in southeastern Ontario, the study examines students' experiences of a career-education program called The Real Game. In this widely used program, grade 7/8 students role-play simulated adult experiences and design life plans for their futures. Given the program's focus on ideals of self-invention, choice, and mobility, I approached The Real Game as a site through which to explore how young people negotiate dominant neoliberal discourses from their embodied locations in social and geographical space.

Rooted in feminist poststructural ethnography, the research involved participant observation, focus groups, and interviews. Rather than claiming to report on a fixed reality, feminist poststructural ethnography explores how truths are produced and contested in context (Pomerantz 2008). During fieldwork, I attended the school three days each week for a period of three months. In addition to observing students' participation in classroom and playground activities, I also elicited their interpretations and reflections through focus groups and follow up interviews. A 
total of 18 focus groups and 20 interviews were conducted with 20 student participants.

This article examines the spatial narratives that emerged during focus groups following two lessons in The Real Game - one in which students created wish lists for their ideal home, and one in which students planned group vacations. Each focus group began with reflections on the recent activity, and then explored related issues that group members raised for discussion. It was in this context that students generated complex narratives about space and place — rural, urban, national, and global.

\section{Locating Self and Others: Rural Youth's Place-Narratives}

"It's Nice, Friendly, and Everybody Knows Everybody": Constructing the Rural Idyll

Author: Imagine that I've never been to this area before. How would you describe Fieldsville to me?

Amanda: It's nice, friendly, and everybody knows everybody.

Kristin: Ya, there's like a hundred people in Fieldsville [laughing], and everybody's ...

Hilary: It's like, "Oh hey!" [as if waving to others she knows]

Rebecca: And everybody knows everyone.

The vision of a small, close-knit community emerges repeatedly throughout focus group discussions. When asked to describe Fieldsville, students speak warmly about a town that's "friendly," "quiet," "nice and peaceful," repeatedly drawing on this same cluster of adjectives to characterize the place they call home. Locating themselves within the natural landscape, students articulate a personal "fit" that is deeply felt:

Hilary: I would live anywhere that's sorta like this town. Like, a small town in the country that just has one little store that you can get stuff there. If it was just like this, then ya. Cuz I like the country, I don't wanna live where there's all traffic. I'm used to the trains. I can get to sleep with those.

Amanda:I love the trains.

Rebecca: And the donkey.

Hilary: And the donkey, and the cows beside us and... [trails off]

Conveying a deep fondness for the sights and sounds of rurality, students locate themselves within the rural idyll, a spatial discourse characterized by themes of nature, safety, and community (Rye 2006).

As students embed their identities within the rural landscape, a gendered mapping emerges in their narratives of rurality. Sharing stories of 
hunting, fishing and riding all-terrain vehicles (ATV's), many Fieldsville boys construct the country as a space where they can engage in activities that are central to their identities:

Cody: For my birthday, I invite all my friends back to the camp...

Paul: Huntin' camp

Cody: And we shoot skeet and everything. We couldn't do that with, if you lived in the city.

Dillon: No. Pull out your gun and a cop would be there in like fifteen seconds.

Cody: We aren't even supposed to be shootin' skeet but we just do anyways for my birthday.

These boys enact rural masculinities characterized by toughness, adventure, and outdoorsmanship (Kenway et al. 2006). Although they speak casually of these activities, their narratives are laced with an air of competition that suggests they must constantly prove themselves as sufficiently rural and masculine.

In contrast to these performances of rural masculinity, Fieldsville girls tend to characterize country living by its close community ties. Laughing, Karen states, "everybody knows everybody. It's like that country song." During focus groups, rural femininities are enacted through spatial stories revolving around the family:

Kristin: My aunt and uncle and cousins live across from me and my great-grandma and my aunt and uncle and other cousins live just down the road from me. And around the corner, up the hill, lives my grandma. So like [laughs]

Rebecca: All of Fieldsville is like my family.

Hilary: I know, same. My whole dad's side of the family, like, my grandma and grandpa live there, and then across the road is my Aunt Debbie, Uncle Harold, like down that way where the dump is. And my aunt and uncle live there too.

Mapping Fieldsville through its familial networks, the girls narrate the roads and hills of their community according to the people one can find there, and the relationships between them. This emphasis on social relations generates a different rural geography from one defined by the mastery of wilderness spaces through hunting and ATVing.

In addition to an appreciation for the natural environment, students' place-narratives echo "the centrality of ideas of safety and security within dominant imaginings of rurality" (Panelli et al. 2004:449. Karen constructs this sense of safety as the natural outcome of a close-knit com- 
munity: "If anything bad happened, there's always people in the village. Even if they don't know you they might know somebody in your family and they'll come and comfort you or something." Fieldsville boys also emphasize safety, but tend to describe it in ways that enact tough masculinities. As Jonathon states: "We live in a small town so it's not like anyone's gonna come in and shoot people." Across these gendered performances, the sense of security is significant to students' understanding of Fieldsville as a place where they belong. In Rebecca's words, "I like living where I know who people are and everything. I know that I'm safe and everything."

Despite this narrative consistency, it would be a mistake to interpret students' investments in the rural idyll as an accurate depiction of their lived geographies. On the contrary, rich analytic space exists between dominant spatial discourses and the everyday experience of place. For instance, students with especially limited material resources experience a disjuncture between their own lived geographies and idealized visions of the rural "home." Christie speaks of the spatial adjustments required by her family's recent move from a house into an apartment, stating: "I'm so used to actually going outside and playing in my backyard, and I can't do that no more." Thus, while students articulate the discourse of the rural idyll with remarkable consistency, their own rural experiences are varied and uneven. Nevertheless, depictions of their rural "home" are often structured around distinctions from the imagined city - a dangerous and exciting space that takes shape in opposition to the rural idyll.

\section{"There's Scary People in the City": Imagining Urban Others}

While students associate Fieldsville with feelings of safety and familiarity, they regard the large, faceless city with suspicion. These young people project their fear of the unknown onto urban bodies, captured in the figure of the "stranger." In Rebecca's words, the city holds "too many people, and too many creepy people." During focus groups I was struck by how frequently students raised concerns about urban crime given that they were usually referring to Warden - the nearest city with a population of roughly 100,000 - which is not known for its high crime rates. These narratives of urban crime sometimes drew on the language of "gangs" and "ghettos," imagery that was most often invoked in the performance of masculinity. Reflecting masculine narratives of risk, Fieldsville boys appeared both frightened by, and enthralled with, what they imagine to be dangerous city spaces. Cody states that "you can't go for bike rides cuz there's scary people in the city." Paul agrees, adding "you go for a bike ride and gangsters jack your bike." When I ask if there 
is anywhere they would not want to visit, these boys connect the space of the "ghetto" with imagery that is explicitly classed, and implicitly racialized:

Paul: The ghetto.

Author: Why not?

Dillon: Cuz you'll get shot.

Author: What do you mean when you say "the ghetto"?

Paul: $\quad$ Like...

Cody: Where all the people live that don't have a lot of money.

Paul: $\quad$ Like Compton, like LA.

Drawing on images they associate with crime-ridden urban spaces, the boys' explanation of the "ghetto" is explicitly classed, evoking imagery of poor, urban communities that are inherently criminal. Paul's reference to Compton - arguably the prototypical "ghetto" of popular culture - reveals the racial coding of this category, calling to mind representations of a poor community of colour, marked by violence.

David Hayes' (2004) research on the urban fantasies of white rap fans in small-town Ontario is one of very few Canadian studies that examine how rural youth's spatial imaginings are both gendered and racially coded. The young men in Hayes' study exoticize the racial Other of the city, and regard urban spaces "with a mixture of awe and fear, wondering how their own masculinity would measure up on the streets of these perilous sites" (2004:67). A similar ambivalence is apparent in Fieldsville boys' narratives of the urban "ghetto." With visible excitement, Paul shares the story of sleeping over at a friend's house in Racklyn, a neighbourhood in Warden that the boys regard as the closest "ghetto" to Fieldsville:

Paul: We were lookin' out [the window] at like, two in the morning and there was this whole gang walkin' by.

Author: How could you tell it was a gang?

Paul: You can tell.

Author: How?

Cody: Who walks in a gang, who ...

Paul: There was like ten guys all wearing their hats and their baggy clothes and everything, smoking ...

Cody: Same coats.

Paul: No. 
Cody: Not the same coats?

Paul: $\quad$ And they had, like, knives and stuff. And Ed [Paul's friend] was bein' stupid and he yelled out the window. I don't know what he yelled, I forget. But we ducked and they stood out there for like ten minutes, starin' at our window. Scared the friggin' crap out of me.

A mixture of experience and imagination inform Paul's account of a night spent inside the Warden "ghetto." Insisting that "you can tell" what a gang looks like, he references the codes that are written onto particular urban bodies, marking them as criminal. The boys view gang culture as something that exists outside of their rural community, yet they easily call to mind representations of what a gang is supposed to look like. Emphasizing "their hats and their baggy clothes," Paul crafts an image found in movies and music videos, often embodied by young men of colour. The power of these images is highlighted by Cody's confident assertion that the gang members were wearing matching coats, despite the fact that he was not present. Exhibiting a mixture of fear and fascination reminiscent of the white male rap fans in Hayes' research, Cody and Paul co-construct their urban imaginings around the "spectacle of the 'Other'" (Hall 1997:225), drawing on essentialist depictions of urban masculinities as racialized, classed, and inherently violent - images that are readily available in a variety of media texts. At the same time that these narratives establish distance from the racial other of the city, they secure the boys' performance of tough, adventurous masculinities.

What complicates these boundary-making practices is the fact that Racklyn is more closely connected to their rural community than the boys' sensationalized stories suggest. Paul's friend, Ed, moved to Racklyn from Fieldsville a few years ago, and Dillon (the third member of this focus group) lived in Racklyn as a child. These two communities actually have similar class compositions, with a large proportion of lowincome households and low levels of formal education. The boys' urban imaginings are all the more striking in light of these shared community features, as they map racialized images of crime onto this space of otherness. Sherene Razack (2002) has demonstrated how mappings of respectable and degenerate spaces are both constitutive of and constituted by racial categories. As these rural youth narrate city spaces through the language of moral contamination, the constructions of "elsewhere" serve to secure their own identities within a countryside that is clean, safe, and implicitly white.

While students tend to construct the city in negative terms, they also mention desirable aspects of urban living, including access to services 
and activities that are not available in Fieldsville. However, when positive features of the city arise during focus groups, they are often met with an ardent defence of rural life:

Kristin: One reason I would want to live in the country is quietness, but I want to live in the city because I'd be so close to everything. I wish it could be the country, but just be like, stores and that in the country.

Amanda: But then it would turn into the city.

Rebecca: And then you'd get all those, like, khaki people that are like, "na-na-na" [sticks her nose in the air and waves her hands in mock snobbery].

Kristin's attempt to contest the rural/urban opposition is quickly overruled by her friends, who remain committed to these categories. The exchange demonstrates that while spatial categories exist along a continuum, binary distinctions exert a powerful influence over their construction. Furthermore, Rebecca's imitation of so-called "khaki people" reveals how rural/urban distinctions are also inflected with class. Implying that an increase in commercial activity would bring an unwelcome influx of city snobs, Rebecca references narratives of urban superiority, where city dwellers are said to look down on "country folk" (Ching and Creed 1997). I return to this spatialization of class later in the article, for it is integral to understanding the dynamics of racialization in students' place narratives.

In summary, even as cities hold the seduction of excitement and entertainment, Fieldsville students remain staunch defenders of their rural community and the lifestyle it represents - a lifestyle that they extend to national space.

\section{"We're the Best Country in the World": Constructing Canada}

Fieldsville students identify strongly with Canada, proudly declaring their membership in what one student calls "the best country in the world." This national affiliation informs students' place-narratives, as they describe Canada in similar terms to their local environment, depicting an expansive landscape that is home to a peaceful national community. In fact, many represent Canada as overwhelmingly rural. When asked how they would describe Canada to someone who has never been here, Kristin and Jessie say:

Kristin: Most of it is countryish, except for like, some of the cities. But like, a lot of Canada is like ... 
Jessie: Country.

Kristin: Ya. Trees and all that stuff.

Jessie: I'd tell them that it's like, a great place for nature and all that.

As the material and symbolic elements of the rural idyll are inscribed onto Canada, the girls characterize the national territory in terms of its rural spaces. Offering a vision of the Canada they know best, this articulation of nation and rurality is supported by a dominant national narrative that defines Canada through its wilderness spaces (Baldwin et al. 2011).

Alongside this preoccupation with physical geography, students also speak about Canada as a safe place to live. They rearticulate narratives of Canada as a steward of global peace, stating "we have peacekeepers, not troops." Many distinguish Canada from other countries by a perceived lack of violent conflict, describing it as a "safe haven" for global migrants. During one focus group, a boys asks, "Did you know that Canada's the only country that has never been bombed? Pretty cool, huh?"

Students were overwhelmingly patriotic in these discussions, identifying with a peaceful, picturesque Canada. Even so, contestation did emerge, as seen in this conversation about Canada's colonial mythology:

Nick: I went to a concert last year and they said that, cuz it was a Native concert, they said that Christopher Columbus didn't find Canada. Cuz it wasn't a new found land because they were already there.

Tim: He found the United States and the ...

Nick: No he didn't. The reason that Newfoundland is called New Found Land is because Christopher ...

Tim: It's a new land and it's been found.

Nick: Ya, cuz Christopher Columbus found it.

Scott: Christopher Columbus was awesome!

Author: Hmm. And so what do you think about that, Nick? Like, were you surprised when you heard that?

Nick: No, not really. I thought about it before that and I said that it didn't make any sense that he found it and they were already there. Did you know that I'm a third Scottish and one of the places in Canada, one of the provinces, is actually called in Scottish, New Scotland? Cuz Scotland found it. But they didn't actually found it because it was already there cuz the Natives were there.

The boys take up various positions in relation to Canada's colonial history, as Nick's initial statement about the presence of Aboriginal people 
prior to colonization is met with a mixture of confusion and resistance. Scott doesn't question Nick directly, but his assertion that "Christopher Columbus was awesome" suggests a personal attachment to masculine narratives of European expansion. Even Nick has trouble sorting out his location within these stories, proudly declaring that Scotland "founded" Nova Scotia, and then revising this statement to acknowledge Indigenous inhabitants. The exchange illustrates how students co-construct placenarratives through which to make sense of their own identities. In doing so, they encounter unresolved questions about the place of Aboriginal people in Canada, who constitute an absent-presence within national mythologies (Razack 2002).

While I do not want to downplay the significance of these moments of contestation, for the most part, Fieldsville students invest as much confidence in dominant national narratives as they do in discourses of the rural idyll. It is against the backdrop of this secure space of national belonging that students look beyond Canada's borders, envisioning other countries with a mixture of curiosity and condemnation.

\section{"It's Cool, but It's Scary": Envisioning Transnational Geographies}

Global spaces take a variety of shapes in Fieldsville students' narratives, ranging from exotic destinations to war-torn regions. Across these narratives, mediascapes play a significant role in shaping students' perceptions of places around the world. This is especially evident in students' depictions of China, one of the possible "destinations" in a classroom activity in which students planned group vacations. Expressing concern about air pollution, Karen references media hype over poor health conditions for athletes at the Beijing Olympics:

They've got too much poison over there. Even in the air. If you just walk through the air, they're used to that air so it doesn't bother them, but since I'm used to this kind of air, the country air, it would really bother me cuz it's going into the big city where there's a lot of factories and smoke in the air and stuff. Like, I think they said when the Olympics were going on that um, they were getting a little bit sick. The Olympians were getting a little bit sick from the air over there.

Karen constructs boundaries that demarcate not only different places, but also different types of people. This is apparent in her suggestion that people in China are accustomed to different air than the "country air" that she's used to - a globalized distinction that maps onto narratives of rural/urban difference.

Other groups contain more striking examples of how place-narratives are inscribed onto bodies. In the following exchange, images of a pol- 
luted China translate into feelings of disgust toward Chinese Canadians, who are positioned as ignorant and abject:

Author: You said you would not want to visit China. Why not?

Rebecca: It's so like, dirty and like ...

Hilary: People don't care there.

Author: What do you mean?

Hilary: I don't think people care because ...

Rebecca:I'd see the Great Wall of China and then leave. Wear one of the gas mask things.

Hilary: I don't know. It just seems weird to me. I don't know what.

Rebecca:Cuz last year Mr. D [a Fieldsville teacher] was always talking about it because he went there and he was like, "It's so dirty, never go there."

Hilary: And we've seen pictures of the place and it looks gross.

Rebecca: And when China people come here they're weird. Like, they're not weird, but like, they talk different and they look different and

Hilary: Ya, there was this Chinese man ...

Rebecca: And they're like, not as smart as us — well, they're as smart as us but they're not like ...

Hilary: They don't know what we know about our country.

Hilary and Rebecca move from descriptions of China as a "dirty" place, to racist assessments of Chinese people as "weird" and ignorant of Canadian ways of life. This interaction reveals how racialized spatial discourses are intertwined with racist ideas about individuals. Drawing on discourses of contamination - both physical and moral - the girls produce images of China that are similar to those referenced by Karen above. Although they don't name media texts explicitly, the China that they imagine appears to be informed by available mediascapes.

Other countries are depicted as dangerous sites associated with images of urban decay. Kristin and Jessie choose Mexico for their Real Game vacation, but explain that they will stay away from Mexico City to avoid "all the bad stuff." When asked to elaborate, they say:

Kristin: Just things I hear like, people say and stuff like that, in my family ... that's how I found out that it was a good place but kind of has bad people and stuff like that.

Jessie: How there's like, kidnappers and killers ...

Kristin: Drug sellers. 
While the girls are wary of the potential "bad people" they might encounter in Mexico, Kristin insists that "we don't care about the race or anything like that." Kristin uses a liberal discourse of equality to distance her own views from those that might be deemed racist. While this "colourblind" approach has serious limitations for addressing racial inequality, the fact that Kristin acknowledges the potential for racism highlights some diversity in perspectives among Fieldsville students.

In contrast to Kristin's careful liberal discourse, some students use overtly racist markers to map global spaces. As Cody, Paul, and Dillon swap friends' stories of trips to dangerous destinations, they enact tough masculinities through racialized spatial narratives that echo their tales of the urban "ghetto."

Paul: It's cool, but it's scary because a girl named Natalie, she graduated last year. She went to Jamaica and she said that there was like, guys walking around with guns and stuff.

Dillon: Guards.

Paul: No! Like, people.

Cody: No, one time Amy Green, they went to Mexico and they were walkin' down the street and there was this black guy sittin' on the wall and he took a handgun and pointed it right at Amy Green and her mom, and the police like, tackled him.

Paul: That'd be scary [laughs].

Here, the boys draw explicit connections between place, race, and deviance, embodied in the figure of the armed black man. Drawing on this same set of associations in a different focus group, Justin explains that he would not want to go to Jamaica because "too much ex-cons go there." He expresses this as a statement of fact, supported by knowledge he has obtained from a relative who works in corrections.

Students struggle to negotiate their own relationship to these racialized spatial discourses. This process is best illustrated by an emotionally charged discussion in which a group of boys discuss their understandings of the war in Afghanistan. When someone mentions Pakistan, Jonathon says, "I don't like calling it Pakistan. I just find it racist." The others explain that Pakistan is the name of a country, not a racist name. I ask Jonathon why he thinks it feels racist to say Pakistan, and he says, "Cuz people call people from Pakistan 'Pakis'." Nick nods, and clarifies: "That's a racist name. But calling it Pakistan isn't." Then, after making this point, Nick exclaims, "But they are Pakis!" For a moment the table is silent. Everyone turns their attention toward Nick, except for Scott, who withdraws, pulling his knees to his chest. "They're total Pakis," Nick says again. When I ask why he would say that, he responds, "Cuz 
I don't mind being racist when they deserve it." At this point, the others jump in. Jonathon bets Nick he wouldn't use that word if "one of them was right beside you," and Tim changes the subject, launching into a fantasy war scene. The discussion continues:

Nick: Calling them Pakis is like calling black people Niggers [Scott gasps]. So it's rude, but ...

Tim: No. Know what'd be cool? Jumping in a jeep in the war! No, after the war's done, jump in a jeep and start drivin' around in the sand! [The others ignore this comment]

Nick: Black people don't deserve it because they've done a lot for white people, but Pakis don't, didn't do anything. They tried to kill all of us.

Scott: [Raises his head from his hands and turns toward Nick] Remember the saying? "It's hard," [pauses, struggling to recall the words from a recent lesson] "it's easy to see how they are the same, it's hard to see how they are different."

Jonathon: No, "It's easy to see how they are different..."

Scott: Oh ya!

Nick and Scott: "It's hard to see how they are the same" [in unison].

Jonathon: Exactly.

Nick: I still call them Pakis.

Nick's racist comments will offend many readers, as they did me. I highlight this excerpt not for its shock value, but as a way to explore how the boys negotiate their own shifting relationship to racist spatial discourses. Jonathon's expressed discomfort surrounding the name of a country demonstrates how racialized spatial discourses are negotiated on an affective level. The others draw on diverse discourses to speak about race and racism, ranging from Nick's assertion of "just deserts," to Tim's strategy of avoidance through fantasy. In the end, the boys help Scott recall the liberal discourse offered in a video they recently watched during a character education lesson on "respect," which had concluded that "It's easy to see how people are different, it's hard to see how they're the same." The exchange reveals that, while pervasive, racialized spatial discourses are a deeply affective and contested, rather than fixed aspect of rural youth's lives.

This interaction also illustrates the racist imagery that young people access through available mediascapes. Recall Nick's distinction that blacks don't deserve racist slurs because they've benefited white people, in contrast to people from Pakistan. This construction of the racial other as alternatively useful or hostile has been linked to moralistic concep- 
tions of hard work within rural communities, a discourse which "separates the deserving from the undeserving" (Sherman 2009:99). Nick's elaboration on this difference appears to be informed by popular culture. From news media to Hollywood films, the figure of the "terrorist" circulates widely throughout contemporary Western media. This "dangerous" other is sustained by racist and Islamaphobic images that have particular salience in this historical moment (Razack 2008; Thobani 2007), and Nick appears to be drawing upon these discourses in his assessment of the racist term "Paki." Situating students' discursive practices within this broader context allows an analysis of how youth draw on broader racial discourses that are widely circulated in popular culture. This also facilitates an understanding of how racism operates through historically constituted racial categories, rather than viewing young people's racist statements as wholly the product of individual prejudice.

What emerges as a common feature across Fieldsville students' varied global depictions is the significance of racial difference in young people's understandings of the world around them, which are always inflected with dynamics of gender, class, and geography. This finding challenges the assumption that issues of race are less relevant within predominately white rural communities that are too often perceived to be disconnected from global processes. What's more, the analysis suggests that these racialized spatial discourses inform rural youth's very sense of self, as their own identities are produced in opposition to racialized, nonrural others. Understanding these dynamics requires an intersectional analysis of whiteness. In the next section, I demonstrate how classed constructions of rurality can provide greater insight into these spatial processes of racialization.

\section{Putting the Rural in its Place: Contradictory Discourses of Rurality in Canada}

Some might interpret students' racialized place-narratives as evidence of widespread racism in rural communities, but such quick explanations obscure the complexity of these accounts. Instead, I argue that students' spatial identifications must be understood in relation to intersecting discourses of race, class, and rurality in Canada. Situating students' placenarratives within this broader context reveals two contradictory discourses that define Canada's rural spaces: one longing for its idyllic rural past, the other lamenting its lagging rural future.

As earlier sections of this article have shown, the rural is attributed value through nostalgic depictions of Canada as an imagined community that is fundamentally connected to nature (Grace 2002). Given that "nature is an important resource in the articulation of whiteness" (Baldwin 
et al. 2011:7), this spatial discourse contributes to the production of a white rural imaginary characterized by notions of physical and moral purity (Shields 1991). Fieldsville students forge their own sense of place within this discursive context. Thus, while aligning themselves with an idealized rural and marking distance from a deviant city, these young people establish themselves as legitimate subjects with a valued place in Canada's settler story.

Contrary to the romanticized rural of Canada's colonial history, contemporary media representations construct rurality as a site of bigotry and ignorance, characterized by a "backward" lifestyle that is contrasted with Canada's progressive city spaces (Corbett 2006). This second discourse of rurality is heavily classed, and works to pathologize workingclass, rural populations. In the words of Michael Corbett, "rurality is powerfully associated with the past, with place ... with stagnation, and with a kind of vague shame. Rural is the place we are supposed to have left behind in the march of history" (2006:295). Pointing toward narratives of rural inferiority that associate the urban with sophistication and progress, and the rural with conservatism and backwardness, Vanderbeck and Dunkley note that "a rural identity is often a stigmatized one" (2003:245).

Even as Fieldsville students identify with the rural idyll, they occasionally acknowledge how their community might be negatively perceived. When asked how she would describe Fieldsville to someone from Toronto, Rebecca says, "you would probably think it was the middle of nowhere." Extending beyond ideas of spatial isolation, the negative association with rurality also suggests something about rural people. In a particularly telling exchange, Justin describes how Fieldsville students are labeled "dirts" when they enter high school in a nearby town:

Justin: My sister gets called a dirt all the time by other kids at [high school] because she went to Fieldsville. Whoever lives here are supposedly "dirts" [uses his fingers to indicate quotation marks].

Author: What does that mean, "dirts"?

Shawn: Dirty.

Justin: Like, dirty people that don't shower and stuff like that. But my family's really clean.

Kyle: Same here.

While at the school, I observed how students used the discourse of dirt to construct classed boundaries around those who were seen to be living in the most severe economic deprivation. Although Fieldsville is largely a working-class community, the "popular" students (who tended to have access to greater resources) labelled those considered to be 
poor as "dirts," a marker that signifies not only physical filth but also moral degeneracy (Douglas 1966; Sibley 1995). In addition to marking class divisions within Fieldsville, Justin reveals how these symbolic boundaries are redrawn at a broader scale. As this polluting category is inscribed onto the community as a whole, students are placed in the impossible position of constantly having to disprove their dirty status.

As a discourse that marks rural, working-class populations, "dirt" has strong connections to the discourse of "redneck." According to Jarosz and Lawson, the term "redneck" circulates as

a largely unproblematized slur against working-class rural people, a generalized assumption about their politics, and a generalizing stereotype about the degeneracy and lack of morality that has historically defined poor people in Euro-American discourse. (2002:12)

They argue that analyzing the redneck discourse is especially pressing in the "contemporary socioeconomic climate, because the livelihoods and futures of working-class people in rural places are in question" (2002:9). In fact, recent research indicates some rural residents are reappropriating the redneck identity as a kind of rural pride, often linked to the performance of rural masculinity. Vanderbeck and Dunkley describe how some Vermont youth from poorer families felt the redneck narrative "ascribed positive characteristics to rural people who were often stigmatized for either their relative poverty or their lifestyle choices" (2003:255). Similarly, O'Connell (2011) points to the rise of the "Canadian Redneck Games" as a celebration of rural whiteness within multicultural Canada. Despite the similarities between "redneck" and "dirt," however, the latter does not afford the same redeeming possibilities. I never encountered a Fieldsville student claiming a form of "dirt" pride. Instead, students describe how this polluting marker operates within geographies of exclusion. In Jessie's words:

You think you're in the prep group and stuff cuz you hang out with them, and you're kind of like, 'Ya, I fit in here.' But then people look at you and they're like, 'No, she's a "dirt",' and then it just brings you right down.

Over the course of my fieldwork, I began to wonder if students' preoccupation with dirt might be interpreted as a response to their rural, classed location. Throughout this article, I have shown how Fieldsville students assign markers of dirt to other people and places, whether explicit (as in the case of China), or implicit (as with the polluted city). I interpret this marking of dirty others as a compensatory practice to secure their own identities within clean, desirable bodies and spaces - what Diane Reay calls "fighting free of negative emplacement" (2000:157). 
Young people work with the discourses available to them in order to create value in the places they call home, and in turn, to disidentify from discourses that pathologize them. Ching and Creed suggest that "when rustics denounce city life they may be deploying an identity politics that challenges urban hegemony and asserts their own value" (1997:18). Faced with classist markers of rural dirt, Fieldsville youth identify with purified images of the rural idyll, which provide a means of valorizing their own location. The fact that this place-based identification is sustained by racist imagery highlights the troubling persistence of deeply racialized spatial discourses in Canada.

Viewed through an intersectional lens, it is possible to see how rural youth may identify with idyllic images of white rurality as a means of defending against classist discourses of rural decline. As students navigate their contradictory locations within overlapping landscapes of the pure and the profane, they inscribe racialized spatial discourses onto various others, while striving to secure their own positions within a white rural idyll.

\section{BEyond "RuRal Racism"}

I have argued that rural youths' racialized place-narratives must be understood through an intersectional lens that attends to gendered and classed performances of rurality and whiteness. In doing so, I want to be clear that I am neither excusing nor downplaying the significance of the students' racist expressions. Rather, I seek to extend the interpretation beyond "rural racism" by showing that these narratives circulate widely through national mythologies and global mediascapes. Accusations of "rural racism" deflect attention away from the need to take collective responsibility for racialized narratives in Canada. Monika Gagnon (2007) documents how expressions of racism during the so-called "Hérouxville Affair" in Quebec were diminished as isolated incidents confined to specific rural municipalities. ${ }^{1}$ This discursive manoeuvre produces urban centres as cosmopolitan and tolerant, elevated against the backdrop of an apparently racist rural periphery. As Gagnon argues, naturalizing racism as an inherent feature of rural space not only "downplays and dismisses such racist behaviour and expressions," but also "marginalizes the need to responsibly address and analyze the violence of such gestures and the

1. In January of 2007, the small town of Hérouxville, Quebec, issued a set of guidelines for prospective immigrants. The list included specific resolutions prohibiting the stoning of women and the covering of one's face, as well as other directives that many critics perceived to be a reflection of "strange fantasies and outdated stereotypes of Muslim culture" (Gagnon 2007:5). 
hostile social climate it creates" (2007:6). In this way, classist assumptions about bigoted rural communities can have the paradoxical effect of sustaining broader systems of white supremacy by locating the problem of racism within an abject, classed category of whiteness (Shirley 2010). Sarah Holloway argues that while there is a need for continued research into the enduring significance of a white rural imaginary, this research must not assume that such notions persist unchallenged. Instead, she suggests that critical studies of race and rurality should also work to "highlight potential moments of frailty in the discursive whitewashing of the countryside" (2007:18).

Representations of rurality proliferate throughout Canadian media and political discourse, most commonly framed by narratives of decline that pit the country's cosmopolitan, urban populations against its apparently old-fashioned rural communities. This article has shown how an intersectional analysis of whiteness can deepen our understanding of the spatial organization of racism, drawing out the class and gender dynamics at play in the construction of a white rural imaginary. Such work is required not only to generate alternative narratives that can counter racist spatial discourses, but also to develop antiracist educational initiatives to address these practices with young people.

\section{REFERENCES}

Baldwin, Andrew, Laura Cameron, and Audrey Kobayashi. 2011. Where is the Great White North? Spatializing history, historicizing whiteness. Pp. 1-15 in A. Baldwin, L. Cameron and A. Kobayashi, eds., Rethinking the Great White North: Race, Nature, and the Historical Geographies of Whiteness in Canada. Vancouver: University of British Columbia Press.

Berger, Carl. 1966. The true North strong and free. Pp. 3-26 in P. Russell, ed., Nationalism in Canada. Toronto: McGraw-Hill.

Braun, Bruce. 2003. "On the raggedy edge of risk": Articulations of race and nature after biology. Pp. 175-203 in D.S. Moore, J. Kosek, and A. Pandian, eds., Race, Nature and the Politics of Difference. Durham, NC: Duke University Press.

Ching, Barbara and Gerald W. Creed, eds. 1997. Knowing Your Place: Rural Identity and Cultural Hierarchy. New York and London: Routledge.

Corbett, Michael. 2006. Educating the country out of the child and educating the child out of the country: An excursion in spectrology. Alberta Journal of Educational Research 52(4):289-301.

Dillabough, Jo-Anne, and Jacqueline Kennelly. 2010. Lost Youth in the Global City: Class, Culture, and the Urban Imaginary. New York: Routledge Falmer. 
Douglas, Mary. 1966. Purity and Danger: An Analysis of the Concepts of Pollution and Taboo. London: Routledge

Furniss, Elizabeth. 1999. The Burden of History: Colonialism and the Frontier Myth in a Rural Canadian Community. Vancouver: University of British Columbia Press.

Gagnon, Monika. 2007. Making (non)sense of L'Affaire Hérouxville. R.A.C.E. Link Spring:4-6.

Goldberg, David Theo. 1993. Polluting the body politic: Race and urban location. Pp. 185-205 in Racist Culture. Cambridge: Blackwell.

Grace, Sherill, E. 2002. Canada and the Idea of North. Montreal and Kingston: McGill-Queen's University Press.

$\mathrm{Ha}$, Tu Thanh. 2009. Dismay in the city, celebration in the country. The Globe and Mail, 06 November: A.4

Hall, Stuart. 1997. Representation: Cultural Representation and Signifying Practices. London: Sage.

Hartigan, John. 2003. Who are these white people?: 'Rednecks,' hillbillies,' and 'white trash' as marked racial subjects. Pp. 95-111 in A.W. Doane and E. Bonilla-Silva, eds., White Out: The Continuing Significance of Racism. New York: Routledge.

Hayes, David. 2004. Fear of (and fascination with) a Black Planet: The relocation of rap by white non-urban youth, Topia 12:63-82.

Holloway, Sarah L. 2007. Burning issues: Whiteness, rurality and the politics of difference. Geoforum 38:7-20.

Jarosz, Lucy and V. Lawson. 2002. "Sophisticated people vs. rednecks": Economic restructuring and class difference in America's West. Antipode 34(1):8-27.

Jones, Owain. 1999. Tomboy tales: The rural, nature and the gender of childhood. Gender, Place and Culture 6(2):117-36.

Kenway, Jane, Anna Kraack, and Anna Hickey-Moody. 2006. Masculinity Beyond the Metropolis. New York: Palgrave MacMillan.

Lawrence, Bonita. 2002. Rewriting histories of the land: Colonization and Indigenous resistance in Eastern Canada. Pp. 21-46 in S. Razack, ed., Race, Space and Citizenship: Unmapping a White Settler Society. Toronto: Between the Lines.

Levine-Rasky, Cynthia, ed. 2002. Working Through Whiteness: International Perspectives. Albany, NY: State University of New York Press.

Little, Jo. 2002. Gender and Rural Geography: Identity, Sexuality and Power in the Countryside. Harlow, England: Prentice Hall.

Mackey, Eva. 1999. The House of Difference: Cultural Politics and National Identity in Canada. London: Routledge. 
Martin, Roger and Richard Florida. 2009. Ontario in the Creative Age. Toronto: Martin Prosperity Institute.

Massey, Doreen. 1994. Space, Place and Gender. Cambridge: Polity Press. 1995. Making spaces, or, geography is political too. Soundings 1:193208.

Mitchell, Clare. 2005. Population change and external commuting in Canada's rural and small town municipalities: 1996-2001. Canadian Journal of Regional Science 3:461-486.

Moore, Donald S., Anand Pandian, and Jake Kosek. 2003. The cultural politics of race and nature: Terrains of power and practice. Pp. 1-70 in Race, Nature and the Politics of Difference. Durham and London: Duke University Press.

O'Connell, Anne. 2010. An exploration of redneck whiteness in multicultural Canada. Social Politics 17(4):536-563.

Panelli, Ruth, Jo Little, and Anna Kraack. 2004. A community issue? Rural women's feelings of safety and fear in New Zealand. Gender, Place and Culture 11(3):445-467.

Panelli, Ruth, Phil Hubbard, Brad Coombes, and Sandie Suchet-Pearson. 2009. De-centring White ruralities: Ethnic diversity, racialisation and Indigenous countrysides. Journal of Rural Studies 25:355-364.

Pomerantz, Shauna. 2008. Girls, Style, and School Identities: Dressing the Part. New York: Palgrave MacMillan

Razack, Sherene. 2002. When place becomes race. Pp. 21-46 in S. Razack, ed., Race, Space and Citizenship: Unmapping a White Settler Society. Toronto: Between the Lines.

2008. Casting Out: The Eviction of Muslims from Western Law and Politics. Toronto: University of Toronto Press.

Reay, Diane. 2000. Children's urban landscapes: Configurations of class and place. In S.R. Munt, ed., Cultural Studies and the Working Class. London: Cassell.

Reay, D. and Helen Lucey. 2000. “I don't really like it here but I don't want to be anywhere else": Children and inner city council estates. Antipode 32(4):410-428.

Rye, Johan Fredrik. 2006. Rural youth's images of the rural. Journal of Rural Studies 22:409-421.

Sherman, Jennifer. 2009. Those Who Work, Those Who Don't: Poverty, Morality, and Family in Rural America. Minneapolis: University of Minnesota Press.

Shields, Rob. 1991. The true north strong and free. Pp. 162-199 in Places on the Margin: Alternative Geographies of Modernity. London: Routledge.

Shirley, Carla D. 2010. "You might be a redneck if..." Boundary work among rural, southern Whites. Social Forces 89(1):35-62. 
Sibley, David. 1995. Geographies of Exclusion. New York: Routledge.

Steyn, Melissa, and Daniel Conway. 2010. Intersecting whiteness, interdisciplinary debates. Ethnicities 10(3):283-291.

Thobani, Sunera. 2007. Exalted Subjects: Studies in the Making of Race and Nation in Canada. Toronto: University of Toronto Press.

Van der Kloet, Marie. 2009. A trip to the coop: The production, consumption and salvation of Canadian wilderness. International Journal of Canadian Studies 39-40:231-251.

Vanderbeck, Robert M. and Cheryl Morse Dunkley. 2003. Young people's narratives of rural-urban difference. Children's Geographies 1(2):241-259.

Wray, Matt. 2006. Not Quite White: White Trash and the Boundaries of Whiteness. Durham, NC: Duke University Press.

Kate Cairns is a Postdoctoral Fellow in Sociology at the University of Toronto. Her work draws upon feminist theory, sociology of education, cultural studies, and critical geography to bring an interdisciplinary approach to questions of power and subjectivity. Kate's research spans the areas of gender, culture, and education, and has appeared in venues such as Gender \& Society, Journal of Consumer Culture, Gender and Education, Ethnography and Education, and The Canadian Geographer. 